\title{
Pengelolaan data dan informasi status gizi balita dan pengambilan keputusan program gizi di puskesmas se-Kabupaten Majene
}

\author{
Shafwan', Hari Kusnanto², Anis Fuad ${ }^{2}$
}

\begin{abstract}
Background: Improved nutritional status is needed throughout the life cycle including children under five. Of age in formulating suitable policies for nutrition improvement program, decision makers require relevant information about nutritional status of the community. The implementation of health information system at District of Majene is not yet optimum. There are some problems such as inaccurate data, inconsistent or unreliable data, delay in data reporting, and processing and presentation of data are rarely made, reporting is done as routine disregarding data quality, there is no feedback from the health office and so on. Decentralization has offered an opportunity for the health center to make its own policy in optimizing nutrition improvement program. However, health centers at District of Majene have never made decisions based on evidence.

Objective: The study aimed to get an overview of data and information management of nutritional status of children under five comprising availability, processing, presentation of data, and the decision making of nutrition program at the health centers of District of Majene.

Method: This was a descriptive case study with qualitative method. Subjects of the study were nutrition staff of the health centers, head of health centers, and head of nutrition section of district health office with health centers and head of health office as analysis units. Data were obtained through indepth interview, focus group discussion, questionnaire, observation, and documentation.

Results: Data and information on nutritional status of children under five years of age were available in all health centers; however format of reporting was unavailable. Data in LB3 accurate, in FIII/gizi and SKDN were inaccurate because there was data manipulation and cadres had limited skills. Data were not valid because there was no signature of head of the health center in the report. Data in FIII/gizi and SKDN reliable, in LB3 not reliable because there was no coordination among staff. Data in SKDN were completed, in FIII/gizi and LB3 incomplete because some of the forms were blank. Data were not provided timely due to less commited cadres, geographical factors, and lack of pressure from the health office. Data were accessible because staff were active in maintaining records. Data were processed manually and presented in the form of narratives, tables and graphs. Decisions made were socialization, counseling, growth monitoring and complementary breastfeeding distribution monitoring. However, they were not based on data so that reports were only made as routine activities.

Conclusion: Data and information on nutritional status of children under five years of age were available at the health centers with quality data in every format of reporting of various kinds. Data and information were processed manually and presented in the form of narratives, tables, and graphs. Decisions made were socialization, counseling, growth monitoring, and complementary breastfeeding distribution monitoring. Decisions made were not based on data available.
\end{abstract}

KEY WORDS data and information, nutrition information, decision making

\section{PENDAHULUAN}

Masalah gizi dapat berdampak terhadap kualitas sumber daya manusia yang sangat diperlukan dalam pembangunan. Gangguan gizi pada balita dapat menyebabkan gangguan tumbuh-kembang pada anak, misalnya: stunted, wasting, dan gangguan perkembangan mental. Anak di bawah umur lima tahun termasuk salah satu kelompok yang berisiko tinggi mengalami gangguan perkembangan fisik apabila ada gangguan gizi (1).

Dalam merumuskan kebijakan atau memilih intervensi yang tepat bagi program perbaikan gizi, para pembuat keputusan dan atau perencana program tentunya memerlukan informasi yang tepat tentang keadaan atau status gizi masyarakat berikut faktor-faktor penyebabnya. Informasi ini seharusnya didasarkan atas laporan-laporan, pengamatan langsung, dan jika perlu didasarkan atas hasil-hasil survei.
Pengambilan keputusan di setiap jenjang dengan menggunakan informasi yang akurat dan evidence based dalam menentukan kebijakan memerlukan sistem informasi yang baik, tepat waktu, dan akurat.

Sistem informasi kesehatan di puskesmas memiliki tanggung jawab untuk melaksanakan kegiatan-kegiatan: pencatatan dan pengumpulan data kegiatan dalam maupun luar gedung, pengolahan data, pembuatan laporan berkala ke dinas kesehatan kabupaten/kota, pemeliharaan bank data, upaya penggunaan data dan informasi untuk manajemen pasien dan unit puskesmas, pelayanan data dan informasi

\footnotetext{
1 Dinas Kesehatan Kabupaten Majene, JI. R.A. Kartini No. 7 Majene Provinsi Sulawesi Barat 91412, e-mail: shaf_nng@yahoo.co.id

2 Magister Sistem Informasi Manajemen Kesehatan, Gedung IKM Lt 3, JI Farmako, Sekip Utara, Yogyakarta 55281
} 
kepada masyarakat dan pihak-pihak berkepentingan lainnya (stakeholders) di wilayah kerja yang bersangkutan (2).

Sejak pelaksanaan desentralisasi sektor kesehatan tahun 2001, sistem informasi kesehatan di berbagai tingkat pemerintahan berjalan kurang lancar, sementara data dan informasi tersebut sangat diperlukan untuk pengambilan keputusan (3). Hal ini dapat dilihat dari penelitian yang dilakukan oleh Halid (4) yang hasilnya membuktikan bahwa pengambilan keputusan manajemen sumber daya manusia di Dinas Kesehatan Provinsi Bengkulu belum sepenuhnya menggunakan SIMPEG (sistem informasi manajemen kepegawaian) sebagai dasar dalam pengambilan keputusan. Triyono (5) juga melakukan penelitian tentang dampak integrasi sistem informasi kegiatan puskesmas terhadap persepsi manfaat data untuk pengambilan keputusan di Kabupaten Kota Waringin Timur. Hasil penelitian tersebut menjelaskan bahwa proses pengumpulan dan pengelolaan data setelah integrasi menjadi lebih efektif, namun persepsi terhadap manfaat data untuk pengambilan keputusan tidak berbeda secara bermakna.

Sementara itu, sistem informasi kesehatan di Kabupaten Majene juga belum dilaksanakan secara optimal. Hal ini dapat dilihat dari adanya beberapa permasalahan yang menyangkut data dan informasi kesehatan, seperti: data yang kurang akurat, inkonsistensi atau data yang tidak reliabel, pengiriman data yang lambat, pengolahan dan penyajian data yang jarang dilakukan, pelaporan yang dilakukan hanya sebatas rutinitas saja tanpa memperhatikan kualitas data, tidak adanya umpanbalik dari dinas kesehatan kepada puskesmas, dan beberapa masalah yang lain.

Berdasarkan sistem informasi kesehatan di Kabupaten Majene tersebut diketahui persentase kunjungan balita ke posyandu (D/S) di kabupaten tersebut berkisar antara $55-65 \%$. Di antara jumlah tersebut (dilihat dari rata-rata selama tiga tahun terakhir), sebanyak $61,95 \%$ balita yang telah mendapat pelayanan di posyandu dan sisanya sebanyak $38,05 \%$ masih belum terlayani oleh posyandu atau tidak terpantau sama sekali. Dengan demikian, sebanyak $38,05 \%$ bayi dan balita dikhawatirkan memiliki potensi menderita kurang gizi bila tidak segera diberi perhatian khusus. Data yang dikumpulkan oleh departemen kesehatan selama tiga tahun terakhir di Kabupaten Majene menunjukkan sebanyak $8,34 \%$ balita menderita gizi kurang dan $3,10 \%$ balita menderita gizi buruk (6).

Melalui sistem informasi yang optimal, puskesmas sebagai sarana pelayanan kesehatan tingkat pertama dalam meningkatkan derajat kesehatan masyarakat melalui perbaikan gizi balita diharapkan dapat mengambil keputusan yang evidence based dalam meningkatkan derajat kesehatan masyarakat melalui perbaikan gizi balita, sehingga persentase balita gizi kurang dapat ditekan dan utamanya balita yang bergizi buruk tidak ditemukan lagi. Oleh karena itu, dalam era desentralisasi sekarang ini menjadi suatu kesempatan yang baik bagi puskesmas untuk menentukan kebijakan sendiri dalam mengoptimalkan program perbaikan gizi, terutama untuk balita sesuai situasi, kondisi, dan kemampuan.
Secara faktual, puskesmas di Kabupaten Majene tidak pernah mengambil suatu keputusan yang evidence based mungkin disebabkan data dan informasi yang akan dijadikan dasar atau acuan dalam pengambilan keputusan masih banyak mengalami permasalahan. Di samping itu, para pimpinan puskesmas di Kabupaten Majene mungkin masih terpola dengan sistem sentralisasi yang hanya menunggu petunjuk dari atas tanpa mau berinisiatif untuk mengambil suatu kebijakan yang sesuai dengan situasi, kondisi, dan permasalahan yang ada di daerah bersangkutan.

Berdasarkan latar belakang tersebut, penelitian ini bertujuan untuk mendapatkan gambaran tentang pengelolaan data dan informasi status gizi balita dan pengambilan keputusan program gizi di puskesmas se-Kabupaten Majene.

\section{BAHAN DAN METODE}

Penelitian ini menggunakan metode kualitatif dengan rancangan penelitian studi kasus yang bersifat deskriptif terhadap pengelolaan data dan pengambilan keputusan program gizi di puskesmas se-Kabupaten Majene, Sulawesi Barat. Subjek penelitian meliputi seluruh petugas gizi dan kepala puskesmas se-Kabupaten Majene, serta Kepala Seksi Gizi Dinas Kesehatan Kabupaten Majene. Unit analisis dalam penelitian ini adalah puskesmas se-Kabupaten Majene dan Dinas Kesehatan Kabupaten Majene.

Teknik pengumpulan data dilakukan dengan observasi (pengamatan), indepth interview (wawancara mendalam), diskusi kelompok terarah (DKT), kuesioner (angket), dan dokumentasi. Observasi dilakukan dengan melihat form FI, FIII/gizi, LB3, dan balok SKDN untuk mengecek atau mencocokkan data yang diperoleh dari hasil wawancara, DKT, dan kuesioner, serta diharapkan dapat menemukan data atau hal yang kemungkinan tidak terungkap oleh responden dalam kuesioner, DKT, maupun wawancara.

Form F1 dan FIII merupakan laporan hasil penimbangan berat badan balita, hanya saja form F1 dibuat oleh posyandu untuk diserahkan ke puskesmas, sedangkan form FIII dibuat oleh puskesmas untuk diserahkan kepada dinas kesehatan setempat. Form Laporan Bulanan (LB3) juga merupakan salah satu sistem pencatatan dan pelaporan terpadu yang dibuat oleh posyandu untuk diserahkan kepada dinas kesehatan setempat, namun laporan ini bersifat lebih umum dibanding form FIII. Balok SKDN ( $\mathrm{S}=$ semua balita, $\mathrm{K}=$ balita dengan kartu menuju sehat/KMS, $D=$ balita yang ditimbang, $N=$ balita yang naik berat badannya) merupakan rekapitulasi dalam bentuk gambar dari hasil pemantauan pertumbuhan balita dengan penimbangan berat badan dari KMS.

Analisis data dalam penelitian ini akan menggunakan model Miles and Huberman (7) yang terbagi dalam beberapa tahapan, antara lain: reduksi data, penyajian data, dan penarikan kesimpulan. Data kemudian diuji menggunakan uji kredibilitas secara triangulasi yang meliputi triangulasi sumber dan triangulasi metode. 


\section{HASIL DAN BAHASAN}

\section{Ketersediaan data dan informasi status gizi balita}

Berdasarkan hasil observasi dan cek dokumen pada 7 puskesmas yang menjadi unit analisis, ditemukan data dan informasi status gizi balita di semua puskesmas seKabupaten Majene telah tersedia, tetapi format pencatatan untuk FI dan balok SKDN di semua puskesmas tidak tersedia (Tabel 1). Hal itu tidak sesuai dengan teori bahwa sistem informasi kesehatan terdiri dari 3 komponen yang saling terkait yaitu: masukan, proses, dan luaran. Salah satu komponen masukan dalam sistem informasi kesehatan adalah instrumen pencatatan dan pelaporan data (8)

Data yang dikumpulkan di posyandu yang seharusnya dicatat dalam format FI tetap tersedia dalam buku catatan kader yang dibuat sendiri. Data yang dikumpulkan di puskesmas tersedia dalam format pencatatan FIII/gizi dan LB3, sedangkan data SKDN yang seharusnya disajikan dalam balok SKDN juga tetap tersedia dalam grafik yang dibuat sendiri oleh petugas di puskesmas. Kemauan dan kemampuan TPG (tenaga pelaksana gizi) dalam menyajikan data dengan membuat grafik sendiri dipengaruhi oleh latar belakang pendidikan gizi yang dimiliki oleh para TPG puskesmas. Dengan demikian walaupun instrumen pencatatan dan pelaporan data tidak lengkap, data dan informasi status gizi balita tetap tersedia. Data yang tersedia diperoleh dari hasil penimbangan rutin di posyandu yang direkapitulasi ke dalam data SKDN dan juga data dan informasi yang diperoleh dari pemantauan status gizi (PSG).

Upaya pemerintah untuk menggunakan informasi kesehatan sebagai pendukung dalam perbaikan sistem kesehatan difokuskan pada tersedianya data yang berguna untuk pengambilan keputusan (9). Pencatatan dan pengumpulan data gizi di semua puskesmas di Kabupaten Majene ditujukan terutama agar keadaan status gizi atau masalah gizi balita di Kabupaten Majene dapat diidentifikasi dengan baik, sehingga data tersebut dapat dijadikan sebagai acuan untuk mengambil suatu keputusan yang tepat dalam memantau atau menangani masalah gizi balita yang ada.
Salah satu permasalahan dan tantangan yang dihadapi dalam sistem informasi kesehatan masyarakat adalah kesadaran akan pentingnya informasi (10). Hal ini sesuai dengan hasil temuan di lapangan yang melaporkan bahwa tersedianya data dan informasi status gizi balita di puskesmas kurang mendapat perhatian dari kepala puskesmas yang ditunjukkan dengan kurangnya pengetahuan kepala puskesmas tentang jenis-jenis format pencatatan data gizi yang digunakan.

Ketersediaan data dan informasi status gizi balita yang akurat Pada penelitian ini, data dikatakan akurat apabila tersedia data dan informasi dalam bentuk FIII/gizi, LB3, dan balok SKDN yang bebas dari kesalahan atau tepat minimal 4 bulan dari 6 bulan terakhir. Menurut Kristanto (11), informasi yang akurat harus bebas dari kesalahan-kesalahan yang menyesatkan bagi orang-orang yang menerima informasi tersebut. Teori ini berbeda dengan hasil temuan di lapangan pada 7 puskesmas yang menjadi unit analisis ditemukan 2 puskesmas (28,6\%) memiliki ketersediaan data dalam format FIII/gizi yang akurat dan 5 puskesmas $(71,4 \%)$ yang tidak akurat, 4 puskesmas $(57,1 \%)$ memiliki ketersediaan data dalam format LB3 yang akurat dan 3 puskesmas $(42,9 \%)$ yang tidak akurat, serta 2 puskesmas $(28,6 \%)$ memiliki ketersediaan data SKDN yang akurat dan 5 puskesmas $(71,4 \%)$ yang tidak akurat. Ketersediaan data dan informasi status gizi balita yang akurat di puskesmas seKabupaten Majene dapat dilihat pada Tabel 2.

Data dalam format FIII/gizi dan SKDN umumnya tidak akurat, sedangkan data dalam format LB3 lebih banyak yang akurat. Hal ini disebabkan data dalam format FIII/gizi dan SKDN merupakan data hasil kegiatan pematauan pertumbuhan balita di posyandu. Data tersebut banyak direkayasa untuk menyesuaikan pencapaian target yang ditetapkan, sehingga data menjadi tidak akurat atau tidak sesuai dengan keadaan yang sesungguhnya di lapangan. Menurut Kristanto (11), dalam penyampaian suatu informasi banyak sekali terjadi gangguangangguan yang dapat mengubah isi dari informasi tersebut. Ketidakakuratan dapat terjadi karena sumber informasi (data) mengalami gangguan atau kesengajaan, sehingga merusak atau mengubah data-data asli tersebut. Sementara itu, data

TABEL 1. Distribusi ketersediaan data dan format pencatatan data gizi di Puskesmas se-Kabupaten Majene

\begin{tabular}{|c|c|c|c|c|c|c|c|}
\hline \multirow{2}{*}{ Puskesmas } & \multicolumn{3}{|c|}{ Data } & \multicolumn{4}{|c|}{ Format Pencatatan/pelaporan } \\
\hline & Dari posyandu & Di puskesmas & SKDN & Fl/gizi & FIII/gizi & LB3 & $\begin{array}{l}\text { Balok } \\
\text { SKDN }\end{array}$ \\
\hline Banggae I & + & + & + & - & + & + & - \\
\hline Banggae II & + & + & + & - & + & + & - \\
\hline Pamboang & + & + & + & - & + & + & - \\
\hline Sendana I & + & + & + & - & + & + & - \\
\hline Sendana II & + & + & + & - & + & + & - \\
\hline Tammero'do & + & + & + & - & + & + & - \\
\hline Malunda & + & + & + & - & + & + & - \\
\hline
\end{tabular}

Keterangan:

+ Tersedia

- Tidak tersedia 
TABEL 2. Distribusi data dan informasi gizi yang akurat di puskesmas se-Kabupaten Majene

\begin{tabular}{lccc}
\hline \multirow{2}{*}{ Puskesmas } & \multicolumn{2}{c}{ Data dalam format pencatatan/pelaporan } \\
\cline { 2 - 4 } & FIII/gizi & LB3 & SKDN \\
\hline Banggae I & - & - & - \\
Banggae II & + & + & + \\
Pamboang & - & + & - \\
Sendana I & - & + & - \\
Sendana II & + & - & - \\
Tammero'do & - & + & - \\
Malunda & - & - & \\
Keterangan: & & & \\
+ Akurat & & & \\
- Tidak akurat & & &
\end{tabular}

dalam format LB3 terdiri dari beberapa komponen, bukan hanya data hasil pemantuan pertumbuhan yang sering direkayasa, sehingga data cenderung lebih akurat.

Data dan informasi yang tidak akurat juga disebabkan oleh rendahnya keterampilan kader dalam mengukur serta penunjukan alat yang digunakan sudah tidak akurat lagi. Penyebab ketidakpastian tersebut adalah bias dan kesalahan acak. Bias diakibatkan oleh kesalahan ketika data diukur, dihimpun, diproses, atau disajikan (12). Hasil penelitian Halid (4) di Provinsi Bengkulu melaporkan bahwa permasalahan yang menjadi kendala pengelolaan SIMPEG adalah sarana dan sumber daya manusia yang kurang memadai. Data dalam format pencatatan juga terdapat banyak coretan yang mengindikasikan bahwa data tidak bebas dari kesalahan-kesalahan.

Ketersediaan data dan informasi status gizi balita yang valid Selain akurasi data dan informasi, kevalidan data juga penting diperhatikan. Data dikatakan valid apabila tersedia data dan informasi dalam FIII/gizi, LB3, dan balok SKDN yang secara sah atau resmi berlaku di wilayah tersebut minimal 4 bulan dari 6 bulan terakhir. Berdasarkan hasil observasi dan cek dokumen pada 7 puskesmas yang menjadi unit analisis, ditemukan 3 puskesmas (42,9\%) memiliki ketersediaan data dalam format FIII/gizi yang valid dan 4 puskesmas $(57,1 \%)$ yang tidak valid, 3 puskesmas $(42,9 \%)$ memiliki ketersediaan data dalam format LB3 yang valid dan 4 puskesmas $(57,1 \%)$ yang tidak valid serta 3 puskesmas $(42,9 \%)$ memiliki ketersediaan data SKDN yang valid dan 4 puskesmas $(57,1 \%)$ yang tidak valid (Tabel 3 ).

Menurut Kadir (12), sumber kesalahan yang mengakibatkan ketidakakurasian data antara lain kesalahan mencatat dan mengoreksi data. Teori ini sesuai dengan hasil yang diperoleh di lapangan yang menemukan ada puskesmas yang memiliki data dalam semua format pencatatan yang valid dan ada juga puskesmas yang memiliki data dalam semua format pencatatan yang tidak valid. Hal ini disebabkan oleh usia dan latar belakang pendidikan kepala puskesmas yang berbeda-beda, sehingga berpengaruh pada tingkat kesadaran akan pentingnya data serta perhatian terhadap data tersebut. Puskesmas yang memiliki data valid pada umumnya memiliki pimpinan berusia produktif dengan latar belakang pendidikan magister kesehatan, sedangkan puskesmas yang memiliki data tidak valid pada umumnya memiliki pimpinan dengan latar pendidikan diploma 1 yang mendekati masa pensiun. Hal tersebut sangat berpengaruh pada besarnya perhatian dan kesadaran akan pentingnya data.

Bukan hanya dipengaruhi oleh pimpinan, kesalahan juga dapat dipengaruhi oleh keaktifan TPG di puskesmas dalam

TABEL 3. Distribusi data dan informasi gizi yang valid di puskesmas se-Kabupaten Majene

\begin{tabular}{lccc}
\hline \multirow{2}{*}{ Puskesmas } & \multicolumn{3}{c}{ Data dalam format pencatatan/pelaporan } \\
\cline { 2 - 4 } & FIII/gizi & LB3 & SKDN \\
\hline Banggae I & - & + & - \\
Banggae II & + & + & + \\
Pamboang & - & - & - \\
Sendana I & + & - & + \\
Sendana II & - & + & - \\
Tammero'do & + & - & - \\
Malunda & - & - & \\
Keterangan: & & & \\
+ Valid & & &
\end{tabular}


melakukan koreksi terhadap data yang ada serta dalam mengupayakan pimpinan puskesmas agar memberikan perhatian pada data yang ada dengan melakukan koreksi.

Data dan informasi status gizi balita yang tersedia di puskesmas umumnya belum valid, dilihat dari beberapa arsip laporan yang tidak ditandatangani oleh kepala puskesmas. Hal ini membuktikan bahwa perhatian kepala puskesmas terhadap data dan informasi status gizi balita tidak maksimal, sehingga waktu untuk mengecek data dengan baik tidak cukup yang akhirnya menyebabkan data atau laporan lebih sering langsung ditandatangani tanpa dikoreksi terlebih dahulu dengan baik. Hasil penelitian Halid (4) membuktikan bahwa kondisi SIMPEG di Dinas Kesehatan Provinsi Bengkulu tidak dikelola secara rapi karena lemahnya perhatian dari pimpinan.

Ketersediaan data dan informasi status gizi balita yang reliabel Data dikatakan reliabel apabila tersedia data dan informasi dalam bentuk FIII/gizi, LB3, dan balok SKDN yang bersifat konsisten dan atau sesuai dengan program lain yang terkait minimal 4 bulan dari 6 bulan terakhir. Pada penelitian ini semua puskesmas (100\%) memiliki ketersediaan data yang reliabel antara data dalam format FIII/ gizi dengan data SKDN, sedangkan 2 puskesmas $(28,6 \%)$ memiliki ketersediaan data yang reliabel antara data gizi dengan data KIA (kesehatan ibu dan anak) dalam format LB3 dan 5 puskesmas $(71,4 \%)$ yang tidak reliabel. Dengan kata lain, data pada 5 puskesmas dalam format LB3 tidak konsisten atau tidak sesuai antara data gizi dengan data KIA (Tabel 4).

Data dalam format FIII/gizi dan SKDN di semua puskesmas bersifat reliabel, sedangkan data dalam format LB3 umumnya tidak reliabel. Hal ini disebabkan data dalam format FIII/gizi dan SKDN bersumber dari data yang dikumpulkan di posyandu. Selain itu, data SKDN juga merujuk pada data yang ada dalam format FIII/gizi. Data dalam format LB3 bersifat tidak reliabel karena antara data gizi dengan data KIA terpisah, ditambah lagi dengan tidak adanya koordinasi dan kerja sama antara pengelola program menyebabkan data menjadi tidak reliabel.
Salah satu aspek komponen proses dalam sistem informasi kesehatan adalah pengorganisasian dan tata kerja unit pengelola data dan informasi yang mencakup aspek koordinasi, sinkronisasi, integrasi, dan kerja sama antarunit pengelola data tersebut (8).

Hasil penelitian juga membuktikan bahwa salah satu faktor yang menyebabkan data dan informasi status gizi balita di puskesmas menjadi tidak reliabel adalah kurangnya waktu bagi kepala puskesmas untuk memantau atau mengoreksi data tersebut. Hal ini sejalan dengan teori yang mengatakan bahwa salah satu sumber kesalahan yang mengakibatkan data tidak akurat adalah kesalahan dalam mengoreksi data (12).

Ketersediaan data dan informasi status gizi balita yang lengkap Data dikatakan lengkap apabila tersedia data dan informasi dalam bentuk FIII/gizi, LB3, dan balok SKDN yang sepenuhnya terisi dalam format pencatatan atau tidak ada kolom isian yang kosong minimal 4 bulan dari 6 bulan terakhir. Hasil observasi dan cek dokumen pada 7 puskesmas yang menjadi unit analisis ditemukan 2 puskesmas $(28,6 \%)$ memiliki ketersediaan data dalam format FIII/gizi yang lengkap dan 5 puskesmas $(71,4 \%)$ yang tidak lengkap, 1 puskesmas $(14,3 \%)$ memiliki ketersediaan data dalam format LB3 yang lengkap dan 6 puskesmas $(85,7 \%)$ yang tidak lengkap, akan tetapi semua puskesmas (100\%) memiliki ketersediaan data SKDN yang lengkap (Tabel 5).

Informasi yang penting bagi pengambilan keputusan adalah kelengkapan data, sehingga dapat mengurangi faktor ketidakpastian (12). Hal ini tidak sesuai dengan hasil yang ditemukan di lapangan yang melaporkan bahwa data dan informasi status gizi balita yang tersedia di puskesmas tidak lengkap yang dilihat dengan adanya kolom isian yang kosong dalam format pencatatan yang digunakan.

Data dalam format FIII/gizi dan LB3 umumnya tidak lengkap, sedangkan data SKDN di semua puskesmas lengkap. Hal ini disebabkan data SKDN dikumpulkan setiap bulan melalui posyandu, sehingga data menjadi lengkap. Data dalam format FIII/gizi dan LB3 tidak terisi secara lengkap karena tidak semua komponen data yang ada dalam format

TABEL 4. Distribusi data dan informasi gizi yang reliabel di puskesmas se-Kabupaten Majene

\begin{tabular}{lccc}
\hline \multirow{2}{*}{ Puskesmas } & \multicolumn{2}{c}{ Data dalam format pencatatan/pelaporan } \\
\cline { 2 - 4 } & FIII/gizi & LB3 & SKDN \\
\hline Banggae I & + & - & + \\
Banggae II & + & - & + \\
Pamboang & + & - & + \\
Sendana I & + & - & + \\
Sendana II & + & + & + \\
Tammero'do & + & - & + \\
Malunda & + & + & + \\
Keterangan: & & & \\
+ Reliabel & & &
\end{tabular}


TABEL 5. Distribusi data dan informasi gizi yang lengkap di puskesmas se- Kabupaten Majene

\begin{tabular}{lccc}
\hline \multirow{2}{*}{ Puskesmas } & \multicolumn{2}{c}{ Data dalam format pencatatan/pelaporan } \\
\cline { 2 - 4 } & FIII/gizi & LB3 & SKDN \\
\hline Banggae I & - & - & + \\
Banggae II & + & - & + \\
Pamboang & - & - & + \\
Sendana I & - & - & + \\
Sendana II & + & + & + \\
Tammero'do & - & - & + \\
Malunda & - & - & \\
Keterangan: & & & \\
+ Lengkap & & &
\end{tabular}

tersebut diperoleh atau dikumpulkan setiap bulan, misal data tentang jumlah bayi dan balita yang mendapat kapsul vitamin A yang hanya diperoleh pada bulan Februari dan Agustus setiap tahun. Selain itu, ketidaklengkapan data juga disebabkan data pada beberapa kolom isian dalam format pencatatan tidak ada, seperti data tentang jumlah ibu hamil dan wanita usia subur yang mendapat kapsul yodium. Data tersebut memang tidak tersedia karena Kabupaten Majene bukan merupakan daerah endemis GAKY (gangguan akibat yodium), sehingga pembagian kapsul yodium tidak dilakukan. Akan tetapi, beberapa puskesmas tidak memberikan simbol tertentu pada kolom isian tersebut, sehingga menimbulkan ketidakpastian mengenai keberadaan data tersebut.

Ketidaklengkapan data dan informasi status gizi balita yang tersedia di puskesmas juga disebabkan tidak tersedianya format pencatatan baku yang digunakan untuk mengumpulkan data dari posyandu, selain juga disebabkan oleh keterlambatan waktu pengumpulan data dari posyandu ke puskesmas. Bahkan tidak jarang pengumpulan data di puskesmas tidak memperhatikan kelengkapan akibat ketergesaan karena sudah melewati batas akhir pengumpulan.

Informasi yang dihasilkan atau dibutuhkan harus memiliki kelengkapan yang baik karena jika tidak lengkap akan mempengaruhi dalam pengambilan keputusan atau menentukan tindakan secara keseluruhan. Hal ini akan berpengaruh terhadap kemampuannya mengontrol atau memecahkan suatu masalah dengan baik (11).

Ketersediaan data dan informasi status gizi balita yang tepat waktu Data dikatakan tepat waktu apabila tersedia data dan informasi dalam bentuk FIII/gizi, LB3, dan balok SKDN yang dilaporkan atau diterima tepat pada waktunya minimal 4 bulan dari 6 bulan terakhir. Berdasarkan hasil observasi dan cek dokumen, ditemukan 3 puskesmas $(42,9 \%)$ memilki ketersediaan data dan informasi status gizi balita yang tepat waktu dan 4 puskesmas $(57,1 \%)$ yang tidak tepat waktu. Data dari posyandu tersebut dikumpulkan ke puskesmas dan data dalam format FIII/gizi serta LB3 dikumpukan ke dinas kesehatan kabupaten sebagai laporan bulanan (Tabel 6).

Informasi yang diterima harus tepat waktu karena jika terlambat diterima, informasi tersebut sudah tidak berguna lagi. Informasi yang terlambat tidak mempunyai nilai yang baik sehingga kalau digunakan sebagai dasar dalam pengambilan keputusan akan berakibat fatal atau kesalahan dalam pengambilan keputusan dan tindakan (11). Pada penelitian ini, keterlambatan data disebabkan ketidakaktifan dan ketidakdispilinan kader dalam mengumpulkan data dan juga dipengaruhi oleh faktor geografis terutama pada daerah

TABEL 6. Distribusi data dan informasi gizi yang tepat waktu di puskesmas se-Kabupaten Majene

\begin{tabular}{lccc}
\hline & \multicolumn{3}{c}{ Data dalam format pencatatan/pelaporan } \\
\cline { 2 - 4 } Puskesmas & FIII/gizi & LB3 & Dari posyandu \\
\hline Banggae I & - & - & - \\
Banggae II & + & + & + \\
Pamboang & - & - & - \\
Sendana I & + & + & + \\
Sendana II & - & - & + \\
Tammero'do & + & - & - \\
Malunda & - & & \\
Keterangan: & & & \\
+ Tepat waktu & & &
\end{tabular}


pegunungan yang aksesnya sangat sulit dijangkau. Penelitian Triyono (5) di Kabupaten Kota Waringin Timur menemukan bahwa keterlambatan waktu pelaporan yang sering dikeluhkan oleh dinas kesehatan disebabkan kondisi geografis yang sulit dijangkau dan sarana transportasi umum yang tergantung pada kondisi cuaca.

Pelaporan data ke dinas kesehatan kabupaten pada penelitian ini juga tidak tepat waktu. Hal ini sangat tergantung pada ketepatan waktu pengumpulan data di puskesmas dari masing-masing posyandu. Jika pengumpulan data dari posyandu ke puskesmas terlambat, maka kemungkinan besar pelaporan data ke dinas kesehatan kabupaten juga terlambat. Selain itu, keterlambatan pengumpulan data juga dapat disebabkan oleh kurangnya perhatian dari pihak dinas kesehatan kabupaten untuk memberikan penekanan agar semua puskesmas disiplin atau tepat waktu dalam pelaporan data.

Ketepatan waktu menyatakan usia data yang sesuai dengan upaya pengambilan keputusan, artinya informasi tersebut tidak usang atau tidak kadaluarsa ketika sampai ke penerima, sehingga masih ada waktu untuk menggunakan informasi tersebut sebagai bahan pengambilan keputusan (12). Akibat dari tidak tepatnya waktu pengumpulan data ke puskesmas atau pelaporan ke dinas kabupaten, data dan informasi status gizi balita itu tidak dimanfaatkan sebagai dasar dalam pengambilan keputusan.

Ketersediaan data dan informasi status gizi balita yang aksesibel Data dikatakan aksesibel apabila tersedia data dan informasi (arsip) minimal 4 bulan dari 6 bulan terakhir yang diperoleh kembali pada hari saat kunjungan ke puskesmas dilakukan atau minimal sehari setelah kunjungan. Ketersediaan data (arsip) yang aksesibel ditemukan pada 4 puskesmas $(57,1 \%)$ dan 3 puskesmas $(42,9 \%)$ lainnya tidak aksesibel. Dengan kata lain dapat dikatakan bahwa data dan informasi status gizi balita yang tersedia di puskesmas (arsip) dapat dengan mudah diperoleh jika sewaktu-waktu dibutuhkan kembali (Tabel 7).

Data sering menjadi kendala utama bagi para pengambil kebijakan untuk mendiagnosis dan memecahkan masalah kesehatan masyarakat karena berbagai masalah dalam menyediakan data yang berkualitas, salah satu diantaranya adalah data tidak siap atau tidak mudah diakses (9). Pada penelitian ini berbeda, karena saat peneliti mencoba meminta data status gizi beberapa bulan yang lalu dapat ditunjukkan oleh petugas selama peneliti masih berada di puskesmas pada hari tersebut. Hal ini juga didukung oleh ketersediaan data hasil rekapitulasi karena kedisiplinan dan keaktifan petugas dalam mengarsipkan data.

Hasil temuan di lapangan ini sesuai dengan teori yang mengatakan bahwa informasi harus dapat disampaikan setiap saat jika dibutuhkan oleh pimpinan. Untuk itu, informasi perlu disusun dan disimpan (arsip) secara sistematis agar mudah ditemukan kembali dengan cepat (5). Namun demikian, beberapa puskesmas memiliki data yang tidak aksesibel. Hal ini disebabkan tidak tersedianya data hasil rekapitulasi akibat dari ketidakaktifan petugas dalam mengarsipkan datanya, sehingga pada saat peneliti mencoba meminta data beberapa bulan yang lalu, petugas tidak dapat menunjukkan data yang diinginkan.

\section{Pengolahan data dan informasi status gizi balita}

Data dan informasi status gizi balita yang diperoleh dari hasil penimbangan rutin di posyandu dikumpulkan di puskesmas kemudian diolah. Semua puskesmas melakukan pengolahan data. Pengolahan data ini ditunjang oleh latar belakang pendidikan TPG yang sebagian besar berpendidikan gizi ditambah dengan kemauan untuk bekerja dengan baik dan profesional.

Salah satu tanggung jawab puskesmas dalam penerapan sistem informasi kesehatan adalah melaksanakan kegiatan pengolahan data (2). Proses pengolahan data yang dilakukan umumnya masih secara manual (Tabel 8). Hal ini disebabkan oleh terbatasnya fasilitas komputer serta kemampuan petugas yang masih kurang. Akan tetapi, ada 2 (28,6\%) puskesmas yang sudah mulai mencoba melakukan pengolahan secara komputerisasi walaupun dengan menggunakan program yang masih sederhana. Hal itu ditunjang oleh adanya fasilitas komputer dan kemampuan petugas menggunakan komputer tersebut. Suatu sistem informasi yang baik tidak harus memiliki komponen teknologi informasi, namun

TABEL 7. Distribusi data dan informasi gizi yang aksesibel di puskesmas se-Kabupaten Majene

\begin{tabular}{lc}
\hline \multicolumn{1}{c}{ Puskesmas } & Aksesibilitas data yang diminta \\
\hline Banggae I & + \\
Banggae II & + \\
Pamboang Sendana I & - \\
Sendana II & + \\
Tammero'do & + \\
Malunda & - \\
Keterangan: & - \\
+ Aksesibel & \\
- Tidak aksesibel &
\end{tabular}


TABEL 8. Distribusi cara pengolahan data gizi di puskesmas se-Kabupaten Majene

\begin{tabular}{lcc}
\hline \multirow{2}{*}{ Puskesmas } & \multicolumn{2}{c}{ Cara pengolahan } \\
\cline { 2 - 3 } & $\begin{array}{c}\text { Manual } \\
\text { (Kertas) }\end{array}$ & $\begin{array}{c}\text { Komputerisasi } \\
\text { (Microsoft Office Excel) }\end{array}$ \\
\hline Banggae I & - & + \\
Banggae II & - & + \\
Pamboang Sendana I & + & - \\
Sendana II & + & - \\
Tammero'do & + & - \\
Malunda & + & - \\
\hline Keterangan: & + & \\
+ Ya & & \\
- Tidak & &
\end{tabular}

keandalan suatu sistem informasi terletak pada keterkaitan antara komponen yang ada sehingga dapat dihasilkan dan dialirkan suatu informasi yang berguna (11).

\section{Penyajian data dan informasi status gizi balita}

Data dan informasi status gizi balita di semua puskesmas pada penelitian ini disajikan dalam bentuk narasi, tabel, dan grafik karena dengan penyajian dalam bentuk tersebut, data yang disajikan lebih mudah diinterpretasikan oleh setiap orang yang melihat atau memanfaatkannya.

Walaupun format pencatatan data dan informasi status gizi balita tidak semuanya tersedia di puskesmas se-Kabupaten Majene seperti balok SKDN, akan tetapi data tetap disajikan dalam bentuk grafik yang dibuat sendiri oleh petugas gizi puskesmas yang menyerupai balok SKDN, sehingga penyajian data SKDN itu tidak persis sama di semua puskesmas.

Tujuan utama suatu sistem informasi adalah dihasilkannya output atau keluaran dalam bentuk informasi dari data yang sudah diolah yang berguna dan dapat dipakai oleh penerima. Agar keluaran itu dapat dipakai dan berguna bagi penerima, maka keluaran itu sebaiknya disajikan sedemikian rupa sehingga lebih komunikatif dan menarik.

\section{Pengambilan keputusan program gizi}

Pengambilan keputusan merupakan tindakan pimpinan untuk memecahkan masalah yang dihadapi dalam organisasi yang dipimpinnya melalui pemilihan satu di antara alternatifalternatif lain yang dimungkinkan (13). Keputusan yang diambil oleh puskesmas pada penelitian ini diimplementasikan dalam berbagai bentuk pelaksanaan kegiatan, antara lain: penyuluhan gizi, konseling gizi di puskesmas, pemantauan pertumbuhan, dan pemantauan pendistribusian MP-ASI.

Berdasarkan hasil wawancara mendalam terhadap kepala puskesmas di Kabupaten Majene, diketahui bahwa keputusan yang diambil oleh kepala puskesmas tersebut merupakan keputusan yang terprogram dan diambil berdasarkan kebiasaan saja tanpa melihat keadaan yang sedang terjadi di masyarakat. Hal ini disebabkan oleh banyaknya kendala atau hambatan seperti tidak tersedianya dana yang cukup. Banyak faktor yang berpengaruh dalam pengambilan keputusan. Faktor tersebut berperan sebagai penghalang yang sangat kuat dan menyebabkan terjadinya block seperti faktor biaya dan faktor politik, sehingga mempersulit penciptaan suatu kultur pengambilan keputusan yang evidence based (14).

Puskesmas di Kabupaten Majene belum dapat mengambil suatu keputusan yang bersifat strategis atau keputusan yang mendukung untuk mengatasi masalah gizi balita di masyarakat. Hal ini diketahui berdasarkan hasil wawancara mendalam terhadap kepala puskesmas bahwa kader sebagai pelaksana teknis di lapangan tidak pernah diarahkan untuk mengambil suatu keputusan jika terjadi masalah di lapangan. Contohnya jika ada balita yang ditimbang 2 kali dan hasilnya menunjukkan bahwa berat badan tetap, maka dengan kondisi seperti itu seharusnya kader diarahkan untuk mengambil suatu keputusan untuk mengunjungi rumah balita dan hal ini yang belum dilakukan. Pengambilan keputusan oleh TPG masih sebatas penyuluhan gizi dan pada tingkatan puskesmas juga belum pernah diambil keputusan yang strategis, misalnya melakukan survei gizi yang sederhana untuk mendapatkan gambaran keadaan status gizi balita yang sesungguhnya di lapangan sehingga keputusan yang diambil lebih evidence based. Dengan demikian keputusan yang diambil hanya sekedar kegiatan rutinitas saja tanpa berdasarkan pada data dan informasi yang ada. Data dan informasi status gizi balita yang tersedia di puskesmas lebih banyak dimanfaatkan hanya sebagai laporan rutin ke dinas kesehatan kabupaten saja. Hasil penelitian Halid (4) membuktikan bahwa akurasi data yang dihasilkan SIMPEG masih diragukan oleh pengambil keputusan, sehingga SIMPEG belum digunakan sebagai bahan pengambilan keputusan.

Sementara itu, peran dinas kesehatan kabupaten dalam mendukung pengambilan keputusan di puskesmas belum nampak. Hal ini ditunjukkan dengan tidak adanya umpan balik yang diberikan dari data yang dilaporkan setiap bulan oleh semua puskesmas, sehingga tidak ada evaluasi terhadap kegiatan sudah dicapai atau dilaksanakan. 


\section{KESIMPULAN DAN SARAN}

Data dan informasi status gizi balita di puskesmas telah tersedia, walaupun tidak ditunjang oleh format pencatatan yang lengkap. Kualitas data yang tersedia di tiap-tiap format pencatatan juga bervariasi. Data dan informasi status gizi balita yang terkumpul di puskesmas kemudian diolah secara manual dan disajikan dalam bentuk narasi, tabel, maupun grafik.

Pengambilan keputusan oleh pimpinan puskesmas hanya sebatas penyuluhan gizi, konseling gizi di puskesmas, pemantauan pertumbuhan, dan pemantauan distribusi MPASI. Hal ini disebabkan oleh banyak faktor, namun faktor yang paling berpengaruh adalah tidak tersedianya dana. Pengambilan keputusan tersebut juga tidak evidence based karena data dan informasi status gizi balita itu tidak berkualitas, sehingga data itu lebih banyak dimanfaatkan hanya sebagai laporan rutin ke dinas kesehatan kabupaten.

Perbaikan sistem informasi dan pengambilan keputusan pada program gizi di puskesmas dapat dilakukan pada tingkat dinas kesehatan kabupaten, puskesmas, maupun pihak atau instansi lain yang berkompeten.

Berdasarkan kesimpulan tersebut, disarankan agar di tingkat dinas kesehatan kabupaten sebaiknya disediakan format pencatatan data yang berkaitan dengan program gizi di tingkat puskesmas, diadakan kerja sama dengan puskesmas dalam pelaksanaan pelatihan atau penyegaran kader secara berkala untuk menambah keterampilan dan pengetahuan kader dalam pengumpulan data gizi, disediakan alat pengukuran

\section{RUJUKAN}

1. Soetjiningsih. Tumbuh Kembang Anak. Jakarta: Penerbit Buku Kedokteran Anak ECG; 2002.

2. Departemen Kesehatan RI. Kebijakan dan Strategi Pengembangan Sistem Informasi Kesehatan Nasional (SIKNAS). Lampiran Keputusan Menteri Kesehatan RI Nomor : 511/MENKES/SK/V/2002; 2002; Jakarta.

3. Budiharto $M$, Hendrawan $H$, Usman $Y$, Suryati $T$. Penyempurnaan Sistem Informasi Kesehatan Kabupaten/ Kota. Abstrak [serial online] 2006 [cited 2007 May 14]. Available from: <http://www.p3.skk.litbang depkes.go.id>.

4. Halid. Pemanfaatan Sistem Informasi Manajemen Kepegawaian sebagai Dasar Pengambilan Keputusan di Dinas Kesehatan Provinsi Bengkulu [tesis]. Yogyakarta: Universitas Gadjah Mada; 2005.

5. Triyono. Dampak Integrasi Sistem Informasi Kegiatan Puskesmas Terhadap Persepsi Manfaat Data Untuk Pengambilan Keputusan di Kabupaten Kotawaringin Timur [tesis]. Yogyakarta: Universitas Gadjah Mada; 2004.

6. Dinas Kesehatan Kabupaten Majene. Laporan Tahunan Gizi Sub Dinas Kesehatan Keluarga Kabupaten Majene; 2004-2006; Jakarta.

7. Sugiyono. Metode Penelitian Kuantitatif, Kualitatif, dan R \& D. Bandung: Penerbit CV Alfabeta; 2006. antropometri yang baru dan komputer untuk pengolahan data di tiap-tiap puskesmas. Selain itu, kepala seksi gizi juga perlu memberikan pembinaan kepada puskesmas yang mengalami banyak masalah dalam pengelolaan data (misalnya kelengkapan, ketepatan waktu pelaporan data, dan lain-lain), memberikan umpan balik, melaksanakan supervisi ke puskesmas, serta memanfaatkan rapat bulanan sebagai sarana untuk mengevaluasi terutama yang menyangkut sistem informasi gizi,perlu lebih proaktif dalam melakukan advokasi kepimpinan eksekutif dan pihak legislatif di kabupaten agar program gizi mendapatkan perhatian yang cukup.

Di tingkat puskesmas, kepala puskesmas perlu memberikan perhatian yang cukup terhadap data dan informasi status gizi balita, memanfaatkan mini lokakarya sebagai sarana evaluasi program gizi terutama mengenai sistem informasinya guna mendukung pengambilan keputusan, dan mengarahkan para kader dan TPG untuk dapat mengambil suatu keputusan jika menemukan masalah di lapangan. TPG puskesmas juga perlu meningkatkan perhatian untuk membenahi data dan informasi gizi yang ada.

Survei gizi yang sederhana juga diperlukan untuk mengetahui keadaan gizi balita yang sesungguhnya di masyarakat serta digunakan untuk membandingkan data dan informasi yang tersedia di puskesmas. Instansi atau pihak yang berkompeten perlu memberikan penghargaan (reward) sebagai motivasi kepada siapa saja yang menemukan dan melaporkan kasus gizi buruk secara dini.

8. Departemen Kesehatan RI. Pokok-pokok Pemantapan dan Pengembangan Sistem Informasi Kesehatan. Jakarta: Depkes RI; 1993.

9. Mendelson DN, Salinsky EM. Health Information Systems and The Role of State Govemment: A Taxonomy and Evaluation of State Govemment Efforts on The Health Information Frontier. Health Aff 1997;16(3):106-19.

10. Kusnanto $H$, Fuad $A$ Sistem Informasi dan Sumber Intelijen Kesehatan Masyarakat. Core Public Health; 2005; Yogyakarta, Indonesia. Yogyakarta: Universitas Gadjah Mada; 2005.

11. Kristanto A. Perancangan Sistem Informasi dan Aplikasinya. Yogyakarta: Penerbit Gava Media; 2003.

12. Kadir A. Pengenalan Sistem Informasi. Yogyakarta: Penerbit Andi Offset; 2003.

13. Syamsi I. Pengambilan Keputusan dan Sistem Informasi. Jakarta: Penerbit PT Bumi Aksara; 2000.

14. Stansfield SK, Walsh J, Prata N, Evans T. Information to Improve Decision Making for Health: Systems and Supply of Health Information. In: Jamison DT, Breman JG, Measham AN, Alleyne G, Claeson M, Evans DB, et al., editors. Disease Control Priorities in Developing Countries. $2^{\text {nd }}$ ed. New York: Oxford University Press; 2006. p. 1017-30. 